\title{
Children in Immediate Danger: Emergency Removals in Finnish and Irish Child Protection
}

Authors: Lamponen, T.; Pösö, T.; Burns, K.

\begin{abstract}
This paper presents a qualitative analysis of front-line practices regarding emergency removals in Finnish and Irish child protection. It examines how the responses to children's immediate danger are framed by legislation and how front-line practitioners assess the child's situation and make emergency placement decisions. The data consists of interviews with 16 Irish and 33 Finnish social workers. These child welfare protection systems respond differently to a task which appears to be similar. The Irish team-based practice rests on the social workers' shared assessment of the child's needs and the formal decision is made by the courts (or police officers at night time); and the Finnish practice involves only one single social worker who makes both the assessment and the removal decision. The Irish system is tightly time-regulated, whereas the Finnish system provides a more flexible time frame. Both approaches put a lot of stress on social workers' practice, which also includes creative workarounds (e.g., 'planned emergency removals' in Finland). Future research will need to explore these features from the point of view of a child's right to protection.
\end{abstract}

Keywords

child protection, cross-country study, decision making, emergency removals, front-line practice

\section{Introduction}

Every child protection system recognizes situations in which a child is in immediate danger and needs urgent protection. Child protection removals are stressful and traumatic events for children, but even more so if the child and her or his parents have not been prepared for the removal, as so often happens in emergency situations (Baugerud \& Melinder 2011; Storhaug \& Kojan 2016). These emergency removals can also be stressful for social workers and other decision makers (Saltiel 2016; Le Blanc et al. 2012). When meeting a child in 'immediate danger', the social worker has to assess the child's situation under time pressures: In emergency situations, a judgment has to be made quickly regarding whether to proceed with an emergency removal or whether there are other ways to help the child and family. Time constraints can impact upon the quality of assessments and decision making as there are fewer opportunities to get extensive information about the child, to weigh up different options, and to examine thoroughly whether the threshold for a removal intervention has been met (Berrick et al. 2016a; Helm 2011; Platt \& Turney 2013; Östberg 2014). The tension between the demand to make a quick decision and the time it takes to gather and revise the information is likely to constrain analytic reasoning (Helm 2011; Saltiel 2016; van de Luitgaarden 2009). Despite the obviously stressful nature of emergency removals, very little research exists about front-line practice in emergency situations (Masson 2002 and 2010; Masson et al. 2007; Storhaug et al. 2016; Storhaug et al. 2018). In particular, the different country responses to 
organising front-line removal practices are only occasionally highlighted in child welfare literature (Burns et al. 2017a; Stafford et al. 2012).

In this paper, we aim to contribute to the existing knowledge base by examining emergency removals in Finland and the Republic of Ireland (hereafter, Ireland). Both countries have emergency removal systems and clearly articulated thresholds for emergency placements. Yet, as the front-line practice of responding to emergency removals is located in the wider social contexts of child welfare (Smith \& Donovan 2003; Glisson et al. 2012; Berrick et al. 2015), there are reasons to assume that there are also some differences that we can learn from. The cultural view on family in Ireland is a mix of traditional values and modernity, with families sharing the responsibility with the state to provide for the needs of people facing social risks (Forsberg \& Toivonen 2018). The Irish child welfare system has historically had high thresholds for access to social services in general, but there is a concerted ongoing process of changing this since the establishment of a new dedicated Child and Family Agency (also known as Tusla) in 2014. Finland, among other Nordic countries, has modernised its family legislation early and provides universal benefits and services to families with children (Eydal \& Kröger 2010).

In comparative child welfare literature, the Irish child protection system belongs to those orientated towards protecting children from risks, whereas the Finnish child protection model is orientated to providing services for children at a low threshold level (Burns et al. 2017a; Pösö \& Huhtanen 2017). The number of children in out-of-home care is considerably higher in Finland than in Ireland: 9.6 per 1,000 children to 5.5 in Ireland in 2012 (Burns et al. 2017a.)

The different system and value orientations motivate us to examine first how the responses to children's immediate danger are provided for in legislation and how front-line practice is organised to meet the criteria set by legislation. We also provide the available statistical information about emergency removals. Second, we analyse how front-line practitioners assess the child's situation and test the criteria for emergency removal and immediate danger within each country. The interviews with 49 social workers make this a study of social work and law-in-action (Dingwall et al. 2014). The findings demonstrate that the legislative and organisational contexts differ, but frontline practices in both countries also share several commonalities. However, there is one fundamental difference in practice: the separation of assessments from decision making in Ireland, whereas in Finland the social worker undertakes the assessment and also makes the removal decision.

\section{The legislative context of emergency removals}

\section{Finland}

Emergency removals make a distinctive category in Finnish legislation (Child Welfare Act 417/2007, Paragraph 38). They belong to the repertoire of out-of-home placements entitled by the Child Welfare Act. Emergency placement can be introduced if the child is in immediate danger (Section 39). In addition, the criteria for a care order should be met. They are as follows (Section 40): 
- The children's health and development is seriously endangered by lack of care or other circumstances in which they are being brought up.

- $\quad$ They seriously endanger their health or development by abuse of intoxicants, by committing an illegal act other than a minor offence or by any other comparable behavior.

- The in-home services would not be suitable or possible for providing care in the interest of the child concerned or if the measures have proved to be insufficient.

- $\quad$ And substitute care is estimated to be in the child's best interest.

Immediate danger is further defined by the Ministry of Social Affairs and Health (Kuntainfo 2015) so that emergency placements are to secure the child's safety in situations in which the child cannot safely stay at home and her or his well-being cannot be safeguarded by in-home measures. The threat to a child's safety can be either physical or mental. Consequently, the threshold for emergency removal of a child into state care is high. The legal implications of the emergency placement are similar to those of a care order: The parents' rights are restricted and restricted measures, such as the restriction of contact and movement, can be introduced during the placement (Pösö \& Huhtanen 2017). In emergency situations, it is also possible to place the child in an out-ofhome placement according to the "in-home services" regulations, which are voluntary and meant to be short term (Paragraph 37); however, we exclude them from our exploration in this paper.

According to Child Welfare Act, emergency placement decisions are made by a social worker and are valid for 30 days. The removal should be terminated when the need expires. This decision can be extended for up to 60 days by a social work manager in the municipal social welfare agency if the period of 30 days is not sufficient to find relevant supportive services for the child and the family, or if the preparations for a care order require more time. All municipalities are obliged to have a social worker available at all times (24/7) to assess children's needs and to make related decisions. The court is only involved in emergency placement decision making in appeal cases. The placement can be either in a foster home or a residential institution. When making the decision, the opinions of the parents and child should be consulted; such consultation may be waived in cases of serious emergency or if special conditions are met (Child Welfare Act 417/2007, § 39a). Besides the legislation and the instructions given by the Ministry of Social Affairs and Health (mentioned above), no nationwide manuals guide social workers in their assessment and decision- making. Consequently, social workers build their decision on their professional interpretation within the provided legal framework.

\section{Ireland}

In Ireland, there are a number of pathways for the reception of a child into state care in emergency situations. Child welfare services in Ireland are typically a weekday, 9 a.m. to 5 p.m. service. Outside of these times, An Garda Síochána (the police) deals with child welfare emergencies. The Child Care Act 1991 empowers the police (under § 12) to enter a home without a warrant and remove a child to a place of safety (foster placement or a hospital). In November 2015, a limited national emergency out-of-hours child welfare social work service was launched to provide social work consultation, advice, and a placement service for An Garda Síochána (Child and Family Agency 2017a). Although this is a national service, there are a few regional social work services providing a more comprehensive service including call-outs, but nowhere near as comprehensive as 
the Finnish 24/7 service. The threshold for an emergency removal by An Garda Síochána under Section 12 of the Child Care Act 1991 is created by exceptional circumstances where

a. there is an immediate and serious risk to the health or welfare of a child and

b. it would not be sufficient for the protection of the child from such immediate and serious risk to await the making of an application for an emergency care order (ECO) by a health board (the Child and Family Agency) under Section 13.

The Child and Family Agency then has $72 \mathrm{hr}$ to decide whether a child can return home or whether to apply to the District Court for an ECO (§ 13), which, if secured, can last for 8 days. A single judge is the decision maker in the District Court, which is the lowest level court in Ireland. During emergency situations occurring during weekdays and daytime hours, social workers in the Child and Family Agency have two options available to them: voluntary care (§ 4) and an ECO (§ 13). In voluntary care, parents can voluntarily agree to their child being placed in state care. Where an agreement cannot be reached, the Child and Family Agency can apply to the District Court for an ECO. Courts can grant an ECO when there is reasonable cause to believe that

a. there is an immediate and serious risk to the health or welfare of a child, which necessitates his or her being placed in the care of a health board (the Child and Family Agency) or

b. there is likely to be such risk if the child is removed from the place where he or she is for the time being (Child Care Act 1991, §13).

National and local guidelines and practice manuals instruct social workers further about how to act in emergency situations.

ECOs can be granted with parental consent, or they can be contested in court. Courts can also grant ECOs on an ex parte basis (i.e., without a parent in court). If the emergency situation has not stabilized and a child needs to stay in state care, the Child and Family Agency would then need to apply to the District Court for an interim care order (ICO), which can last for 29 days, and this order can be renewed on an ongoing basis.

In sum, legislation in both countries puts a high threshold for removing a child in emergency situations if voluntary services are not sufficient. There must be a clear and immediate danger and serious risk posed to the child. Both countries also have established practices in such situations, which in Finland are called "emergency placements" and in Ireland are called ECOs. Decision makers differ considerably (judge in a court vs. social workers). These will be explored further in the following sections.

\section{The profile of emergency removals in Finland and Ireland}

The numbers of emergency removals are presented in the annual Finnish national welfare statistics, whereas the Irish numbers are not available in the same way. Table 1 presents, however, the 
existing information, demonstrating a considerable difference in the numbers. The emergency removals are much more common in Finland (3,625 in 2015) than in Ireland (944 in 2015).

Table 1: Statistics on emergency removals (total number during the year) and the number emergency removals as a percentage of all children under 18 in Finland and Ireland*

\begin{tabular}{|l|l|l|l|l|}
\hline & $\mathbf{2 0 0 0}$ & $\mathbf{2 0 0 5}$ & $\mathbf{2 0 1 0}$ & $\mathbf{2 0 1 5}$ \\
\hline Finland ${ }^{(1)}$ & $940 / 0.1 \%$ & $1,672 / 0.2 \%$ & $3,412 / 0.3 \%$ & $3,625 / 0.3 \%$ \\
\hline $\begin{array}{l}\text { Ireland, } \\
\text { emergency } \\
\text { care orders } \\
\text { (District } \\
\text { Court) }{ }^{(2)}\end{array}$ & No data available & No data available & No data available & $236 / 0.02 \%$ (Tusla ECO data) \\
\hline $\begin{array}{l}\text { Ireland, } \\
\text { section 12 } \\
\text { emergency } \\
\text { removals by }\end{array}$ & No data available & No data available & or \\
$\begin{array}{l}\text { An Garda } \\
\text { Síochána (3) }\end{array}$ & & 349 / 0.03\% (Courts service ECO data) \\
\hline
\end{tabular}

The amount of emergency placements has grown constantly during the 21st century in Finland (as shown in Table 1). It has been speculated that the growth reflects the changes in the child protection system and its decision-making system since the latest Child Welfare Act was introduced in 2007 (Lamponen 2016; Pösö \& Huhtanen 2017). Also, child protection practitioners have experienced heavy caseloads in the last decade, and there have been insufficient appropriate preventative services, which may have led to more families ending up in crisis and children experiencing immediate danger. The existing reports suggest that emergency removals are linked with parents' substance abuse and mental health problems, as well as with adolescents' behaviou r. Roughly half of the children are between the ages of 13 and 17 (Pösö \& Huhtanen 2017). In addition, children are often placed in emergency care repeatedly, and especially teenagers often are taken into care as a continuation from an emergency placement (Lamponen 2016).

The Court Service (2017) annual report in Ireland highlighted that District Courts grant a high percentage of the ECO applications made by the Child and Family Agency: 349 of 357 ECO applications were granted in 2015. This data are in conflict with Tusla data on ECOs, which noted that there were 236 ECOs in 2015. Tusla's figure represented 15\% (236 out of 1,550) of all legal reasons for admissions to care (Child and Family Agency 2017b). There were 365 Section 12 outof-hours removals by An Garda Síochána in 2012 and 402 in 2013 (Burns et al. 2017b) and a markedly higher removal rate of 718 in 2015 (Shannon 2017). In the most recent Tusla "adequacy” report (Child and Family Agency 2017b), 528 children were placed in emergency accommodation in 2015 and there were 251 children (4\% of the total number of children in care) in emergency care at the end of December 2015. ECOs and ICOs were more likely to be used for younger children, 
with 30\% of children in care being aged 0-4 years in care at the end of December 2015 (24\% on an ICO and $4 \%$ on an ECO), which is a markedly different profile to the Finnish data presented above.

Research-based knowledge about emergency placements in Finland is very limited (Berrick et al. 2016). Although there has been a significant amount of legal research on the Child Care Act 1991 in Ireland, until recently, there has been little empirical research on the day-to-day operation of the Act, particularly the sections that facilitate the out-of-home placements of children. However, two significant studies have recently reported their findings on District Court child care proceedings (Burns et al. 2018; Coulter et al. 2015; O`Mahony et al. 2016a; O`Mahony et al. 2016b; Parkes et al. 2015). A further recently published study by Shannon (2017) was critical of the operation of Section 12 by An Garda Síochána. He noted poor staff training for members of An Garda Síochána tasked with child protection removals after hours, and he was also critical of the level of communication between An Garda Síochána and Tusla, the Child and Family Agency. Furthermore, the new limited out-of-hours social work service to support An Garda Síochána was deemed inadequate due to its limited scope.

\section{Research design}

As the interest of this study is to explore how the front-line practice of emergency removals is organized and how everyday practice is carried out in these two countries, semi-structured interviews were undertaken with child protection workers in Finland and Ireland. Interview guides included questions about "who, how, when and why" regarding the situations in which a child is in immediate danger, followed by questions about the interviewees' views on the present model and decision-making processes. They were also asked to describe one recent case and the concrete process of decision making in the selected case. The social workers invited to describe their experiences of what supported or inhibited their practice in emergency cases. The interviewees are experts in this research subject; hence, there was also unstructured time designed into the interview to allow for discussion on unplanned themes. The same researcher, the first author of this paper, undertook all of the interviews.

The interviews with Irish social workers $(\mathrm{N}=16)$ in child protection teams in four Tusla offices took place between March and December 2015, including 11 social workers, four social work team leaders and one team manager (duty, intake, children in care, and fostering teams). In Finland, the interviews with social workers $(\mathrm{N}=33)$ were carried out as part of an ethnography study of the first author of this paper in three local child protection agencies in two Finnish municipalities during 2015-2016. One of the agencies provides social services in emergency situations of any kind on a 24/7 basis, whereas two agencies worked only during office hours on weekdays. The study received ethical approval from the ethics committee of the University of Tampere, Finland. Institutional approval was also sought and secured from relevant organizational bodies in both countries: Tusla, the Child and Family Agency (in Ireland), and municipal social protection agencies (in Finland). Permission was obtained from the team managers, and then interviews were agreed in co-operation with the local teams. The team managers asked volunteers to participate in the study in Ireland, whereas in Finland the researcher directly asked social workers to participate in the study. 
The interview data was coded into themes using thematic analysis (Goffey \& Atkinson 1996). The data was treated in a naturalistic way (see Gubrium \& Holstein 2007) as a description of the practice given in the interview situation. The analysis focused first on how front-line social work is organized when a child in immediate danger becomes known to the agency. This is presented in the first empirical section. The second empirical section presents our analysis of how child protection practitioners talk about how they assess the needs of children in emergency situations and whether the threshold for an emergency removal had been met.

\subsection{Limitations}

In cross-country research, it is important that the complexities of each system and local nuances are accounted for in the study design and analysis. The analysis of the interview data was done in the original languages of the interviews, and translation took place only when presenting the findings. All of the research teams have practice and research expertise in one of the countries, and two team members could work both in English and in Finnish. This expertise, together with a regular checking process, ensured that an accurate picture of each system was portrayed and the analysis of the data from each country was grounded in local knowledge. Yet the risk of underinterpretation/overinterpretation of the differences and similarities across the countries remains, as the practices are embedded in complex social, historical, and cultural contexts. The lack of previous research on emergency removals did, in addition, challenge the analysis and interpretations. Due to the scale and nature of this study, the empirical findings should not be generalized to describe all the practices of emergency removals in either country. Further largescale studies to cover a greater number of municipalities/local authorities in both countries is required. In addition, as the focus was strictly on emergency removals, other forms of removals (such as voluntary placements in urgent situations), were excluded from the paper. Other important elements, such as the impact of emergency removals upon social workers' welfare, need to be the focus of future papers. In this paper, we also do not address the placement options for children, nor the overall workloads of practitioners and their impact on front-line practice with children in immediate danger. Nevertheless, we argue that it is important for social work practice to learn about the everyday experiences of how practices operate in different country contexts. For an individual social worker, such an analysis may highlight the strengths and weaknesses of her or his own practice and country context, which may otherwise remain unnoticed.

\section{Empirical findings}

\subsection{Two models of organising the front-line practice: Team response versus single social worker}

There are two different models for organizing the front-line practice of social workers who meet children in immediate danger: The Irish practice is organized in teams, whereas the Finnish model is the practice of one social worker. The different models of professional practice are also materialized by the physical organization of practice in the agencies studied. The Irish social workers are physically located close to each other in open office spaces, whereas the Finnish social workers have their own private rooms or share their room with one colleague. In both countries, the team managers have private offices located close to the team. 
The Irish team-based practice functions, in general, as follows. For new referrals, the team manager calls up the team and organizes the different tasks for each team member to assess a child's situation. Several social workers work together in order to collect information, write documents, and meet the parties involved. In the end, the manager makes the decision based on the information and proposal given by the social worker team about whether to proceed to court, whether voluntary care can be agreed on, or whether the child's needs could be met otherwise, with the child staying at home with an agreed safety plan. This model creates a team response, as stated by one interviewee:

In emergency situations like I said it'll be a team response. It's [that] there is so much work to be done and it needs to happen so quickly. There is a mountain of paperwork to be done: there's getting in contact with the fostering service to try and get a foster family. I suppose we'll do that earlier on, we'll give them a warning earlier on. There's possibly being with a child and interviewing the child. There's involving the Gardaí [police] if there's criminal [issue] ... if we have information that a crime's been disclosed. There's having to ... hear the parents, there's ringing the solicitor to see if there's a court available to try and get us a slot, an early slot in the court, to try and gather information for instance that we may already know about the family. There's an awful lot of work to be done at that time, so, it will be a team response. (Team leader, Interview 9, Ireland)

This extract summaries the typical Irish team response evident in all interviews: It is an intense process in which the work is divided between the team members in order to assess the child's situation thoroughly. The team-based approach also means that the overall the responsibility of decision making and the pressure of the workload are shared.

The Finnish model rests formally on the single practitioner making the assessment and eventually the decision, as mandated by legislation. Nevertheless, social workers often work in pairs, and there is easy of access if they wish to consult their partner and also wish to consult other colleagues or a team leader for their opinion. Some practitioners actively consult the team leaders for their opinions and instructions, especially in complex situations, and the views of the team leaders are seen as being important:

It is, after all, a big decision for the child and the family. It's best for all the participants and for my own legal protection that there is another person making the assessment and possibly managers' support ... obviously it is not possible every time. (Social worker, Interview 2, Finland)

As the social worker points out in this extract, it is not every child whose case is dealt with by several practitioners. The interviewee accepts the situation as it is: "Obviously it is not possible every time”. The standard is one single social worker working with the child in immediate danger, and other colleagues' or a team leader's involvement is a deviation from the standard. The team leaders become involved later if the parents or a child appeals the decision: 
Well, a manager's opinion is required afterwards in cases where someone has appealed or something else like that. Our manager would not particularly get involved otherwise. (Social worker, Interview 4, Finland)

In this and the previous interview extract, the model of one social worker working with the children in immediate danger is vulnerable from a legal point of view. First, the social worker's legal protection was mentioned, and then the likelihood of the appeal made by parents and/or children was mentioned. Yet it remains the choice of the social worker to ask another practitioner to become involved.

\subsection{Assessments and decisions in front-line practice}

Social work assessments include a variety of negotiations of thresholds and constant sense-making of the child's situation (Helm 2016; Platt \& Turney 2013; Saltiel 2015). The making of a formal decision about emergency removals includes the use of statutory authority. In the two models of front-line practice described above, the Irish teams make assessments of the child's situation and decide whether to take the case to the court or not, whereas the single Finnish social worker makes both the assessment and the formal decision of the emergency removal. Consequently, social workers' tasks in these countries differ considerably. The Finnish social worker is the ultimate decision maker, making a professional assessment of the child's situation and making a decision with public power. In the case of a child in immediate danger in Ireland, the case is presented to a judge in the District Court who undertakes an independent test of the evidence and weighs the evidence against the ECO threshold. We now describe in more detail how the tasks are carried out and viewed by the practitioners in these two models.

In their teams, the Irish social workers collect information and assess the children's situations with reference to the ECO criteria. Tasks are divided, and information collected, shared, and tested by the team and the team leader. Shared assessment and the delegation of tasks are an important part of practice: Emergency situations require processes that are rapid, as the "window" for decisionmaking is short. If there is a reason to think that an emergency removal is required, the court proceeding is normally on the same day. The decision to bring an application for an emergency order to the court is ideally required by midday due to the courts' timetable. If the team is unable to gather enough evidence before this time, the decision-making is shifted to the next day. Awareness of the tight time schedule is embedded in the assessment work:

If an emergency comes in, I suppose the first thing we usually do is have a meeting in the office. The team leader and maybe two, three social workers, usually a few people are involved. Then we would sit down and discuss the process. We all know that court has to happen within 24 hours. (Social worker, duty team, Interview 5, Ireland)

Even when a single social worker does some parts of the assessment, the assessment is tested with colleagues and a team leader. In the extract below, the social worker describes what she or he has 
done and how the team and the leader became involved in assessing the nature of the information and his or her view:

You got an emergency in and like I was saying you go out and you meet the child and you meet with the parent. Then you phone in and you say this information: this child needs to come into care and I want to do this, and you just would let them (team leader and colleagues) know. And then obviously they'll listen to your information and if they have any objections if they said, look there's a gap in the information here you need to go get that, then you follow that direction. (Interview 2, social worker, Ireland)

The team leader may also be actively involved in the process of collecting information, as was described by one team leader:

I do go on the visits with them, I do sign off on everything, I do tell them, email me, text me... (Team leader, Interview 6, Ireland)

When collecting information about the child's situation, social workers weigh up the potential harm to a child if they stay with her or his family, and also the harm if the child is removed. The struggle of how to correctly make sense of and assess what can sometimes be incomplete information or evidence is often described by social workers in both countries. However, it is especially the Irish social workers who make a distinction between "soft" and "hard" evidence and how important it is to get hard evidence (facts) instead of impressions or hearsay. They also emphasize more the shared elements of testing information. Shared testing is done, although the team leaders make the judgement about the information available. This is highlighted in the following quotation:

And I do it in consultation with them. I say, "What do you believe should be done here?" and usually we'd be at the same page, and I question them in certain things or I'd ask them to go back to get more information on certain things before I make my decision. But ultimately, I'm the one who's making the decision. (Team manager, Interview 1, Ireland)

Very differently from their Irish colleagues, a single social worker in Finland collects and examines the information for both the assessment and decision about the removal, writes the documents including the formal removal decision - and decides about the placement. She or he might eventually take the child to the emergency foster home or institution. Sometimes, the tasks are shared, especially in complex cases. Also, the younger and less experienced the social workers are, the more they consult their colleagues. Younger social workers expressed their wish to learn from their more experienced colleagues how to assess the child's situation and how to map the assessment onto the threshold criteria. If there is a colleague involved in the process, there is more confidence in the decisions made. The quality of assessment can also be improved by disagreement, articulated by other social workers; in these situations, the social worker in charge of the case needs 
to rethink her or his view of the case. A shared understanding of the situations can be equally important:

It's so important that you have an opportunity to discuss... Maybe you need some kind of a confirmation from your pair and manager when you are uncertain. (Social worker, Interview 5, Finland)

In situations in which the social workers were not quite certain whether the child was in immediate danger, the Finnish social workers employed a strategy of separating the assessment from the decision; here we call these "planned emergency removals". We did not come across such planned emergency removals in the Irish system. In planned emergency removals, the assessment is made much earlier than the actual decision. The child is typically known to child welfare services for a longer period of time, and her or his situation had been assessed several times. The situations have been such that it had not quite met the criteria for a child protection removal, but then there was a crisis which trigged a decision, like the one described below:

If the situation has been acute, in some cases the crises situation can be relieving, as finally it's possible to somehow go forward. Maybe you have considered the out-ofhome placement for a longer time and then there is an emergency situation; it is an opportunity to act. (Social worker, Interview 16, Finland)

The crisis could be of different kinds: A teenager known to the agency due to several child welfare notifications runs away from school and is found heavily drunk, and this new information could bring the case across the threshold. In such cases, the social worker would already have quite a lot of information about the child and the family, and the decision would be based on the existing information, in addition to the new situation of immediate danger. For the social worker who is solely in charge of the child's removal, a crisis in the child's life may be "a relief”, as stated in the previous extract. The new event, can be a tipping point, a trigger (Kettle 2017; Storhaug et al. 2018), which makes the decision for an emergency removal clearer. This trigger may have similar meaning as "hard evidence" referred to by the Irish interviewees to help and streamline the professional judgement of the case.

Both Irish and Finnish social workers talked about shortage of time in which to do the tasks required. If there was not enough time to collect information and test it; social workers would sometimes extend their working hours to become certain that the child was safe. The Irish social workers make a safety plan for the child if they run out of time to get the case to the court. The safety plan may include a solution that an adult, familiar to the child, agrees to take care of the child until the next day. An Garda Síochána may also be involved in monitoring the situation overnight. The Finnish social workers instead call the social workers in emergency services who work at night and weekends and ask them to continue working with the child after their working hours. In turn, the social workers doing night or weekend work can pass the child to the daytime social workers if the case is not finished during their working shift. This means that the agency hours do not restrict 
the work done with the child: There is always a social worker to assess the situation and make a removal decision if needed.

\section{Discussion and concluding comments}

When a child is in immediate danger, the child protection system needs to act quickly. The Irish team-based response is organized in such a way that it is efficient in collecting the information, testing it, and taking it quickly forward to the court. This organizational model also provides a platform for constant reflection for practitioners in which the information, thresholds, and evidence are tested, and the assessment workload is shared. The Finnish system of a single social worker relies on the psychosocial expertise of the practitioner. It can also be quick and free from strict time frames as the social worker can make the removal decision by herself or himself. There should also always be a social worker taking care of a child known to be in immediate danger as the services are available 24/7.

The interviews with the social workers highlighted some weak points in their systems. The Irish response is not flexible enough to meet children's needs in the later hours of the day or at weekends, leaving the responsibility for taking care of the child to police officers with the support of a telephone-based social worker for support if necessary or to relatives and friends implementing a safety plan. For a child in immediate danger and also needing psychosocial support, there may also be weaknesses in the police response (see Shannon 2017). Police officers with varying experience of child protection have to decide how to deal with children at risk, often without sufficient training. The quality of the Finnish responses can be threatened by the practice of relying on one single social worker and her or his understanding of the case. The thresholds, for example, can vary between social workers due to the lack of shared practices, which increases the variability of decisions within the country, often seen as being a critical element for sound decision making (Keddell 2014). In the stressful situations of emergency removals, the wide area for discretion may make social workers feel vulnerable, leading them to look for a consultation with their colleagues and team leaders. The shared practice is not, however, a standard practice as it is in Ireland. The vulnerability of the Finnish practice is highlighted when compared to the Irish way of organizing the front-line practice, which emphasizes the shared elements: verbalizing the different elements of information, doubts, and concluding assessments. The shared model is also likely to decrease the emotional burden on social workers related to these emergency removals.

In sum, we have shown above how differently these two child protection systems respond to children in child protection emergencies in front-line practice. The responses mirror the overall features of the countries' approaches to children and families in vulnerable situations. The Irish child protection system sets high criteria for services in child protection in general. This is reflected in an intense, time aware, and shared model of emergency removals, employing the court as a decision maker. The Finnish child protection system in general provides services at a low threshold, and a single social worker is given a wide area of discretion and time frame to work with children. The finding that Ireland has a significantly lower number of emergency removals than Finland may be related to the high thresholds for removals and the constitutional protection afforded to the family in Ireland. The differences in volume follow, after all, the overall pattern of out-of-home care in both countries. This study's findings certainly pose a question for future studies: What 
approach to emergency removals best supports a child's right to protection in immediate danger in the best and most humane way? The everyday professional practices of responding to an immediate danger to a child allows us to see some of the interconnections between social workers' tasks, models of decision-making, values, and the orientation of each child welfare system towards children and families, which is shaped by - and which may also shape - national child protection legislation and policy.

\section{References}

Baugerud, G., \& Melinder, A. (2011) Maltreated Children`s Memory of Stressful Removals from Their Biological Parents. Applied Cognitive Psychology, 26(2), 261-270.

Berrick, J., Peckover, S., Pösö, T., \& Skivenes, M. (2015) The formalized framework for decision making in child protection care orders: A cross-country comparison. Journal of European Social Policy, 25(4), 366-378. doi:10.117770958928715594540

Berrick, J., Dickens, J., Pösö, T. \& Skivenes, M. (2016) Time, institutional support and quality of decision making in child protection care orders: A cross-country analysis. Human Service Organizations: Management, Leadership \& Governance.

http://dx.doi.org/10.1080/23303131.2016.1159637

Burns, K., Pösö, T., \& Skivenes, M. (Eds.) (2017a) Child Welfare Removals by the State: A CrossCountry Analysis of Decision- Making Systems. New York: Oxford University Press.

Burns, K., O`Mahony, C., Shore, C., \& Parkes, A. (2017b) Child removal decision-making systems in Ireland: Law, policy and practice. In K. Burns, T. Pösö \& M. Skivenes (Eds.) Child Welfare Removals by the State: A Cross-Country Analysis of Decision-Making Systems (pp. 146-173). New York: Oxford University Press.

Burns, K., O`Mahony, C., Shore, C., \& Parkes, A. (2018) What social workers talk about when they talk about child care proceedings in the District Court in Ireland. Child and Family Social Work, 23 (1), 113-121.

Child and Family Agency (2017a) Annual Report 2016. Dublin: Tusla, Child and Family Agency.

Child and Family Agency (2017b) Annual Review on the Adequacy of Child Care and Family Support Services Available 2015. Dublin: Tusla, Child and Family Agency.

Coffey, A. \& Atkinson, P. (1996) Making sense of qualitative data: Complementary research strategies. Thousand Oaks: Sage. 
Coulter, C., Colfer, L., Healy, K., \& MacMahon, M. (2015) Final Report. Child Care Law Reporting Project. Available at http://www.childlawproject.ie/interim-reports/ (accessed $5^{\text {th }}$ June 2017).

Courts Service (2017) Courts Service Annual Report 2016. Dublin: Courts Service.

Dingwall, R., Eekelaar, J., \& Murray, T. (2014) The Protection of Children. $2^{\text {nd }}$ ed. New Orleans: Quid Pro Books.

Eydal, G. \& Kröger, T. (2010) Nordic family policies: constructing contexts for social work with families. In H. Forsberg \& T. Kröger (eds.) Social Work and Child Welfare Politics. Bristol: The Policy Press, 11-28.

Forsberg, H. \& Toivonen, V. (2018) The future of the family as envisioned by young adults in Ireland. Journal of Youth Studies, 21(6), 765-779.

Glisson, C., Philip G., \& Williams, N. (2012) Assessing the organizational social context (OSC) of child welfare system: implications for research and practice. Child Abuse \& Neglect, 36(9), 621632.

Gubrium, J. \& Holstein, J. (1997) The New Language of Qualitative Method. New York, USA: Oxford University Press.

Helm, D. (2011) Judgement or assumptions? The role of analysis in assessing children and young people`s need. British Journal of Social Work, 41(5), 894-911.

Helm, D. (2016) Sense-making in a social work office: an ethnographic study of safeguarding judgements. Child and Family Social Work, 21(1), 26-35.

Keddell, E. (2014) Current Debates on Variability in Child Welfare Decision-Making: A Selected Literature Reviews. Social Sciences 3, 916-940. Doi: 103390/socsci34040916.

Kettle, M. (2017) The tipping point: fateful moments in child protection. Child and Family Social Work, 22(4), 31-39.

Kuntainfo (2015) Lastensuojelun kiireellistä sijoitusta koskevat muutokset 1.1.2016 [Information to the municipalities 2015. The changes regarding emergency placements in child welfare 1.1.2016]. Available at http://stm.fi/documents/1271139/1427058/Kuntainfo_8_2015.pdf/ce4381e3-f4134c06-945e-73ede882b565 (accessed 12th December 2017).

Lamponen, T. (2016) Kiireellinen sijoitus vai minihuostaanotto? [The emergency placement or a small care-order decision?] In R. Enroos, T. Heino \& T. Pösö (Eds.) Huostaanotto. Lastensuojelun vaativin tehtävä [Care order. The most demanding task in child protection] (pp.126-140). Tampere: Vastapaino. 
Lastensuojelu (2016) [Child Welfare 2015] Statistical report 43/2017. Helsinki: Terveyden ja hyvinvoinnin laitos.

Lastensuojelulaki 417/2007. [Child Welfare Act] Available at http://www.finlex.fi (accessed 17th March 2016).

LeBlanc, V., Regehr, C., Shlonsky, A. \& Bogo, M. (2012) Stress responses and decision making in child protection workers faced with high conflict situations. Child Abuse \& Neglect, 36, 404-4012.

Masson, J. (2002) Police protection- protecting whom? Journal of Social Welfare and Family Law, 24(2), 157-173.

Masson, J., McGovern, D., Pick, K., \& Winn Oakly, M. (2007) Protecting Powers. Emergency Interventions for Children`s Protection. Chichester: John Wiley.

Masson, J. (2010) Emergency protection: the impact of court control on safeguarding children. Family Law, 40, 1088-1093.

O`Mahony, C. Burns, K., Parkers, A., \& Shore, C. (2016a) Representation and participation in child care proceedings: what about the voice of the parents? Journal of Social Welfare and Family Law, 38(3), 302-322.

O`Mahony, C. Burns, K., Parkers, A., \& Shore, C. (2016b) `Child care proceedings in nonspecialist courts: the experience in Ireland International Journal of Law Policy and the Family, 30, 131-157.

Parkes, A, Shore, C., O`Mahony, C, \& Burns, K. (2015) `The right of the child to be heard? Professional experiences of child care proceedings in the Irish District Court . Child and Family Law Quarterly, 27(4), 423-444.

Platt, D., \& Turney, D. (2013) Making threshold decisions in child protection: A Conceptual analysis. British Journal of Social Work, 6(1), 1472-1490.

Pösö, T., Huhtanen, R. (2017) Removals of children in Finland: a mix of voluntary and involuntary decisions. In K. Burns, T. Pösö \& M. Skivenes (Eds.) Child Welfare Removals by the State: A Cross-Country Analysis of Decision- Making Systems (pp. 18-39). New York: Oxford University Press.

Saltiel, D. (2016) Observing front line decision making in child protection. British Journal of Social Work, 46(7), 2104-2119. 
Shannon, G. (2017) Audit of the Exercise by An Garda Síochána of Section 12 of the Child Care Act 1991, Dublin, An Garda Síochána.

Smith, B., \& Donovan, S. (2003) Child welfare practice in organizational and institutional context. Social Service Review, 77(4), 541-563.

Sotkanet. [Statistical information on welfare and health in Finland] Available at https://www.sotkanet/fi/index (accessed 6th March 2018).

Stafford, A., Parton, N., Vincent, S., \& Smith, C. (2012) Child Protection Systems in the United Kingdom. A Comparative Analysis. London: Jessica Kingsley Publisher.

Storhaug, A. S., \& Kojan, B. H. (2016) Emergency out-of-home placements in Norway: Parents' experiences. Child \& Family Social Work, 22(4), 1407-1414.

Storhaug, A. S., \& Kojan, B. H., \& Fjellvikås, G. (2018) Norwegian child welfare workers’ perceptions of emergency placements. Child \& Family Social Work.

https://doi.org/10.1111/cfs.12599

van de Luitgaarden, G. M. J. (2009) Evidence-based practice in social work: Lessons from judgement and decision-making theory. British Journal of Social Work, 39(2), 243-260.

Östberg, F. (2014) Using 'Consensual Ideology': A Way to Sift Reports in Child Welfare. British Journal of Social Work, 44, 63-80. 